\title{
Late Neoproterozoic granitoid and metavolcanic rocks of the Indian Brook Area, southeastern Cape Breton Highlands, Nova Scotia
}

\author{
Laura E. Grecco' and Sandra M. Barr ${ }^{2}$ \\ ' Departamento de Geología, Universidad Nacional del Sur - CONICET, \\ San Juan 670, 8000 Bahía Blanca, Argentina \\ ${ }^{2}$ Department of Geology, Acadia University, Wolfville, N.S., Canada BOP IXO
}

Date Received: July 30, 1998

Date Accepted: February I, 1999

\begin{abstract}
Late Neoproterozoic granitoid rocks constitute most of the Indian Brook area of the southeastern Cape Breton Highlands. They are divided into seven map units based on field relations, texture, and mineralogy. Although sharp lithological contacts have been mapped in the field, the plutons are chemically gradational, and are inferred to be a comagmatic suite. related by crystal fractionation processes and/or variable amounts of melting of similar source rocks. Composition in the largest pluton, the ca. $100 \mathrm{~km}^{2}$ Indian Brook Granodiorite varies from more mafic in the northwest to more felsic in the southeast, consistent with pressures estimated from the Al-in-hornblende geobarometer which suggest that the western part represents the deeper part of the pluton. Volcanic rocks of the Price Point Formation and the chemically similar Murray Mountain Quartz Monzodiorite occur in the southeastern part of the area, and are inferred to represent the highest level of emplacement and accompanying extrusion of magma. The granitoid and volcanic rocks have petrochemical features consistent with origin in a continental margin subduction zone, like other units of similar age in the Bras d'Or terrane.
\end{abstract}

La roche granitoïde Néoprotérozoique tardif constituent la majeure partie de la région d'Indian Brook au sud-est des hautes terres du Cap Breton. Elles sont divisées en sept unités de carte basées sur des observations sur le terrain, la texture, et la minéralogie. Bien que de forts contacts lithologiques aient été tracés dans sur le terrain, les plutons sont chimiquement graduels, et sont déduis pour être un groupe comagmatique, associée par les processus de cristallisation fractionnée et/ou des quantités variables de la fonte de roche similaire à la source. La composition dans le plus grand pluton, $\mathrm{c} .100 \mathrm{~km}^{2} \mathrm{de}$ granodiorite D'Indian Brook a une variation de mafique dans le nord-ouest à felsique dans le du sud-est, conformé à des pressions estimées à partir du géobaromètre d'Al-dans-homblende qui suggèrent que la partie occidentale représente une part plus profonde du pluton. Les roches volcaniques de la Formation Price Point et les roches chimiquement semblables de Murray Mountain Quartz Monzodiorite on lieu dans la partie sud-est de la zone, et sont impliquées pour représenter le niveau le plus élevé de la mise en place et l'accompagnement de l'extrusion de magma. Les roches granitoìdes et volcaniques ont les dispositifs pétrochimiques conformés à l'origine dans une zone continentale de subduction de marge, comme d'autres unités d'âge semblable dans le terrane de Bras d'Or.

[Traduit par la rédaction]

\section{INTRODUCTION}

Late Neoproterozoic granitoid plutons and minor metavolcanic rocks form most of the southeastern Cape Breton Highlands (Fig. 1). Although the area has been mapped in detail (Barr et al. 1992; Lynch and Lafrance 1996), previous petrological studies are limited. Barr et al. (1982) reported petrochemical data from only the southernmost part of the area, and Macdonald and Barr (1985) presented a revised interpretation of the geology of the same area, with limited new geochemical data. Some chemical data for the area were presented by Farrow and Barr (1992) and Dostal et al. (1996), but they were part of more regional studies and did not emphasize units of the southeastern highlands. Hence the present study was undertaken to focus on the petrology, petrogenesis, and tectonic setting of Late Neoproterozoic units in this area.

Further study was needed to help resolve differing interpretations of these units. In one interpretation (e.g., Barr and Raeside 1989; Farrow and Barr 1992; Raeside and Barr 1990) the plutonic and volcanic rocks are considered to be typical of the Bras d'Or terrane, and therefore unrelated to rocks of similar age in the Mira terrane of southeastern Cape Breton Island (Fig. 1, inset). In contrast, Dostal et al. (1996) did not recognize these separate terranes, and related all of the Late Neoproterozoic plutonic and volcanic rocks to a single evolving subduction zone. Different interpretations have also been made of the relationship between the mainly granodioritic and granitic plutons of the southeastern Cape Breton Highlands and the mainly dioritic and tonalitic plutons farther to the northwest. Based on geobarometric and geochronologic data, Farrow and Barr (1992) postulated that all of these rocks are related, and represent different levels of erosion within a continental margin subduction zone. In contrast, Lynch (1996) proposed the presence of a major fault (part of his Highlands Shear Zone) along the western margin of the Indian Brook Granodiorite. Rocks to the northwest of this structure were designated part of the southern lobe of the 


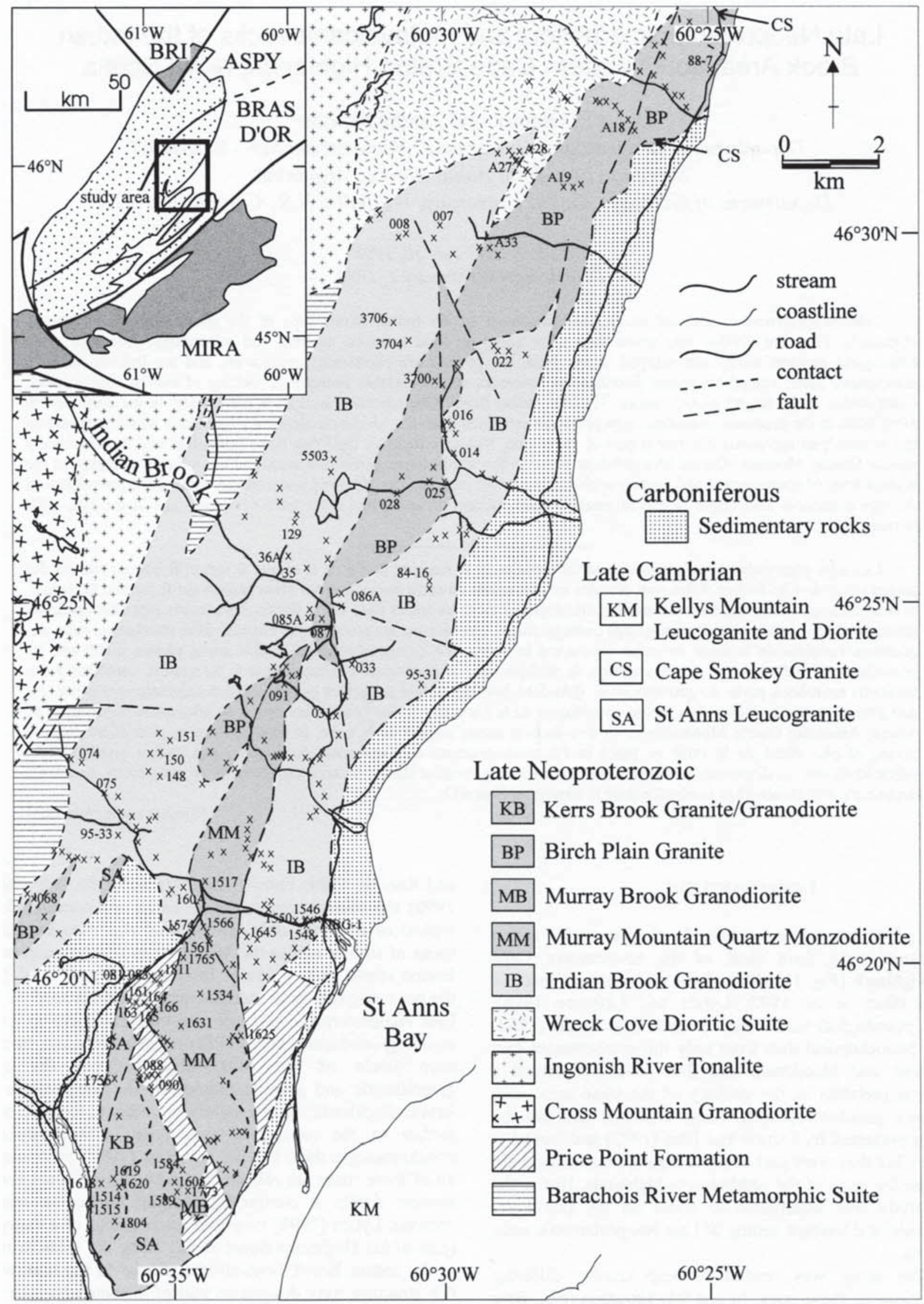

Fig. 1. Simplified geological map of the southeastern Cape Breton Highlands, after Barr et al. (1992). Sample locations are shown by x's; numbered localities are locations of samples listed in Table 1 and/or Table 4 (designated by last few digits of the sample number). Inset map shows terranes in Cape Breton Island, after Barr et al. (1995); BRI, Blair River Inlier. 
Cabot Nappe, inferring that they are unrelated to those to the southeast.

The purpose of this paper is to describe the petrochemical characteristics of the major Late Neoproterozoic plutonic units of the southeastern Cape Breton Highlands (Barr et al. 1992), including the Indian Brook Granodiorite, Birch Plain Granite, Murray Mountain Quartz Monzodiorite, Murray Brook Granodiorite, and Kerrs Brook Granite, as well as associated low-grade metavolcanic rocks of the Price Point Formation (Fig. 1). Amphibole compositions in the Indian Brook Granodiorite are used to assess the depth of emplacement using the $\mathrm{Al}$-in-hornblende geobarometer (Hammarstrom and Zen 1986; Schmidt 1992). The data are used to discuss the relationships among and petrogenesis of the volcanic and plutonic rocks. They do not resolve all of the conflicting interpretations noted above, but provide a contribution toward that goal.

\section{GeOLOGICAL SETTING}

The study area is part of the Bras d'Or terrane (Fig. 1, inset) of Barr and Raeside (1989). This terrane is characterized by low-pressure, high-grade metamorphic rocks, variably metamorphosed continental margin clastic-carbonate sequences, relatively minor metavolcanic rocks, and Late Neoproterozoic plutonic rocks (Raeside and Barr 1990). The terrane has been tentatively correlated with similar areas in both southern Newfoundland and New Brunswick (Raeside and Barr 1990; Barr and White 1996; White and Barr 1996; Barr et al. 1995, 1998), but its regional significance and relationship to the adjacent Mira terrane are controversial (e.g., Keppie et al. 1990; Barr et al. 1990; Dostal et al. 1996; Keppie et al. 1998).

The southeastern highlands part of the Bras d'Or terrane (Fig. 1) consists mainly of an elongate granodioritic pluton, ca. $100 \mathrm{~km}^{2}$ in area, named the Indian Brook Granodiorite (Barr et al. 1985; 1992). The granodiorite is divided into eastern and western parts by the Birch Plain Granite and, farther south, the Murray Mountain Quartz Monzodiorite (Fig. 1). The Price Point Formation occurs in the southern part of the area, adjacent to the Murray Mountain Quartz Monzodiorite. Smaller plutonic units in the area include the Kerrs Brook Granite, Murray Brook Granodiorite, and Late Cambrian St. Anns Leucogranite (Fig. 1), as well as abundant granitoid dykes and plutons too small to show on Figure 1. These various plutonic units have been distinguished from one another based on detailed mapping and petrographic study, including modal mineralogy (Barr et al. 1982, 1985, 1992; Macdonald and Barr 1985). The distinctive features of these plutons indicate that Lynch and Lafrance (1996) were not justified in re-assigning all or parts of these units to the Indian Brook Granodiorite.

Relative ages of these granitoid units on the basis of field relationships are not definitive. Macdonald and Barr (1985) inferred an intrusive sequence based on the composition of cross-cutting granitoid dykes; however, re-examination of the dyke samples during the present study suggests that their postulated correlation with specific granitoid units is uncertain. Nevertheless, it seems likely that, with the exception of the younger St. Anns Leuocogranite (see below), the Price Point Formation and associated granitoid units are comagmatic. Their age is interpreted to be approximately 575 - $565 \mathrm{Ma}$, based on U-Pb dating of zircon and titanite which has demonstrated maximum and minimum ages of crystallization of $575 \mathrm{Ma}$ and $564 \mathrm{Ma}$ for the Indian Brook Granodiorite (Dunning et al. 1990). In contrast, the St. Anns Leucogranite is inferred to be Late Cambrian in age because it is identical in appearance and composition to the Kellys Mountain Leucogranite, located southeast of St. Anns Bay (Fig. 1), which has yielded a U-Pb (zircon) age of $493 \mathrm{Ma}$ (Dunning et al. 1990). Hence the St. Anns Leucogranite is not included in the present study.

On its western margin, the Indian Brook Granodiorite is in contact (from north to south) with the Wreck Cove Dioritic Suite, Ingonish River Tonalite, and Barachois River Metamorphic Suite (Barr et al. 1992). The Wreck Cove and Ingonish River units are two of the ca. 565 - 555 Ma plutonic units that comprise most of the northwestern part of the Bras d'Or terrane (Farrow 1989; Farrow and Barr 1992). The Barachois River Metamorphic Suite (termed the Barachois River gneissic complex by Lynch and Lafrance 1996) consists of potassium feldspar augen gneiss interlayered with semipelitic gneiss and rare mafic gneiss; it is of uncertain age and origin (Raeside and Barr 1992). Because xenoliths of all of these units were observed in the western part of the Indian Brook Granodiorite, Barr et al. (1992) inferred that the Indian Brook Granodiorite intruded the adjacent units. In contrast, Lynch and Lafrance (1996) showed a thrust fault along the western margin of the Indian Brook Granodiorite, with the western units thrust over the Indian Brook Granodiorite. Field observations to justify this interpretation have not been published, but it appears incompatible with the observed xenoliths in the Indian Brook Granodiorite.

Locally, Carboniferous sedimentary rocks unconformably overlie or are in faulted contact with the metamorphic, volcanic, and plutonic rocks around the periphery of the area (Fig. 1).

\section{Petrography}

\section{Indian Brook Granodiorite}

The Indian Brook Granodiorite is the largest unit in the study area. It is typically composed of dark red, medium- to coarse-grained granodiorite which contains 15 to $20 \%$ mafic minerals, including both hornblende and biotite. Other major minerals are plagioclase (oligoclase-andesine), perthitic microcline, and quartz. The texture is inequigranular, with a framework of euhedral and subhedral plagioclase and mafic minerals separated by interstitial microcline and quartz. Abundant large (up to $2 \mathrm{~mm}$ in length) interstitial grains of titanite are typically present; other accessory minerals include zircon, apatite, and magnetite. The western part of the unit generally contains more mafic minerals than the eastern part. Alteration is more intense in the eastern part, and includes moderate to intense saussuritization and sericitization of plagioclase, chloritization of biotite and hornblende, replacement of hornblende by actinolite, and pervasive epidotization and hematitization. 


\section{Birch Plain Granite}

The Birch Plain Granite is medium grained, pale pink to red, and contains less than $10 \%$ biotite; no hornblende is present. Other major minerals are plagioclase (oligoclase), strongly perthitic microcline, and quartz. The texture is mainly medium to coarse grained and equigranular, although locally it is porphyritic with phenocrysts of microcline up to 3 to $4 \mathrm{~cm}$ in length. Allanite and zircon are abundant accessory phases, together with titanite, apatite and magnetite. In places, a weak to moderately strong foliation is present, defined mainly by biotite alignment. It is not clear whether this is a magmatic or tectonic foliation.

\section{Kerrs Brook Granite}

The Kerrs Brook Granite is similar in appearance to the Indian Brook Granodiorite but generally has fewer mafic minerals (less than $15 \%$ ), and is more granitic. In contrast to the Birch Plain Granite, the mafic minerals include both hornblende and biotite. Texture is coarse grained and allotriomorphic equigranular. Titanite, apatite, and magnetite are abundant accessory phases.

\section{Murray Brook Granodiorite}

The Murray Brook Granodiorite is similar to the Indian Brook Granodiorite in texture and mineralogy, but forms a separate body in the southern part of the study area. It could be part of the Indian Brook Granodiorite, but Macdonald and Barr (1985) interpreted it to be a separate unit, based in part on the presence of intense hydrothermal alteration, quartz-calcite veining, and sulphide mineralization.

\section{Murray Mountain Quartz Monzodiorite}

The Murray Mountain Quartz Monzodiorite varies in texture from fine-grained porphyritic to medium-grained inequigranular, and contains abundant hornblende and biotite (20 to $25 \%$ in total). Quartz and minor perthitic K-feldspar are interstitial. In places, these interstitial minerals are somewhat intergrown, approaching a granophyric texture. These features, as well as the close association with volcanic rocks of the Price Point Formation, suggest that the pluton was emplaced at a shallow crustal level.

\section{Price Point Formation}

The Price Point Formation consists dominantly of lithic and crystal tuff of andesitic and dacitic composition. Possible flows of similar composition are a minor component and occur mainly in the western part of the unit. Mafic dykes are present, but similar dykes also occur in the associated plutons, so it is not clear that they are part of the volcanic package. Most of the volcanic rocks consist mainly of subhedral plagioclase and amphibole crystals. The rocks have been affected by lowgrade metamorphism and alteration, and contain abundant chlorite, epidote, actinolite, calcite, quartz, sericite, and opaque minerals. Plagioclase is moderately saussuritized.

\section{WHOLE-ROCK GEOCHEMISTRY}

\section{Indian Brook Granodiorite}

A total of 28 analyses are available from the Indian Brook Granodiorite (Table 1), and an additional 2 analyses from the pluton were reported by Dostal et al. (1996). Because of the large size of the pluton, the samples are divided into four groups based on geographic area in order to assess internal variations within the pluton - northwest of Indian Brook, southest of Indian Brook, northeast of Indian Brook, and southeast of Indian Brook (Fig. 1). Dostal et al. (1996) did not report specific sample locations but their two samples are likely to be from the southeastern area which includes the major road section through the unit.

On average (Table 2), the 8 samples from the northwestern part of the unit have lowest $\mathrm{SiO}_{2}$ contents (average $62.5 \%$ ), whereas the 8 samples from the southeastern area (6 from this study and two from Dostal et al. 1996) have the highest $\mathrm{SiO}_{2}$ contents (average 67\%). Most major elements show correlation with $\mathrm{SiO}_{2}$ (e.g., Fig. 2), and hence the samples from the southeastern area are generally lower in $\mathrm{TiO}_{2}, \mathrm{Al}_{2} \mathrm{O}_{3}, \mathrm{Fe}_{2} \mathrm{O}_{3}{ }^{\mathrm{t}}, \mathrm{MnO}, \mathrm{MgO}, \mathrm{CaO}$, and $\mathrm{P}_{2} \mathrm{O}_{5}$, and higher in $\mathrm{K}_{2} \mathrm{O}$ than the samples from the northwestern area of the pluton, and samples from the other two areas have intermediate compositions (Table 2; Fig. 2). On a Q-A-P diagram using CIPW normative mineralogy (Fig. 3), the samples are mainly granodiorite, but range from quartz monzodiorite (northwestern area) to monzogranite (southeastern area). Among the trace elements, the samples from the southeastern area are lower in $\mathrm{Sr}, \mathrm{V}$, and $\mathrm{Pb}$, but higher in $\mathrm{Rb}, \mathrm{Th}$, and $\mathrm{Nb}$ (Table 2). Other elements such as $\mathrm{Pb}, \mathrm{Zr}, \mathrm{Ga}, \mathrm{Y}$, and $\mathrm{Nb}$ do not show significant variation. Overall, the chemical characteristics of the granitic part of the pluton (southeastern part) are similar to those of the average Itype granite of Whalen et al. (1987), although lower in $\mathrm{Pb}$ (Fig. 4a).

\section{Birch Plain Granite}

Nine samples from the Birch Plain Granite range in $\mathrm{SiO}_{2}$ from 70 to $74.7 \%$, with an average value of $71.9 \%$. They show some compositional overlap with granitic samples from the southeastern part of the Indian Brook Granodiorite, and lie on the same trends on silica variation diagrams (Fig. 2) and on the Q-A-P diagram (Fig. 3). Hence, although contacts appear sharp between these units in the field, chemical relationships appear gradational. With respect to trace element components, the granite samples tend to contain lower $\mathrm{Zn}, \mathrm{Sr}, \mathrm{P}, \mathrm{Zr}, \mathrm{V}, \mathrm{Ga}$, and $\mathrm{Y}$ compared to the Indian Brook Granodiorite, consistent with the higher $\mathrm{SiO}_{2}$ content (Table 2). The average Birch Plain Granite is similar in $\mathrm{Ba}, \mathrm{K}, \mathrm{Nb}, \mathrm{Zn}, \mathrm{P}, \mathrm{Zr}, \mathrm{V}$, and $\mathrm{Ga}$ to the average felsic I-type granite of Whalen et al. (1987), but lower in $\mathrm{Pb}, \mathrm{Rb}$, and $\mathrm{Th}$ and higher in $\mathrm{Sr}$ (Fig. 4b).

\section{Kerrs Brook Granite}

Nine samples from the Kerrs Brook Granite, including 2 samples from Dostal et al. (1996), show a narrow range in 


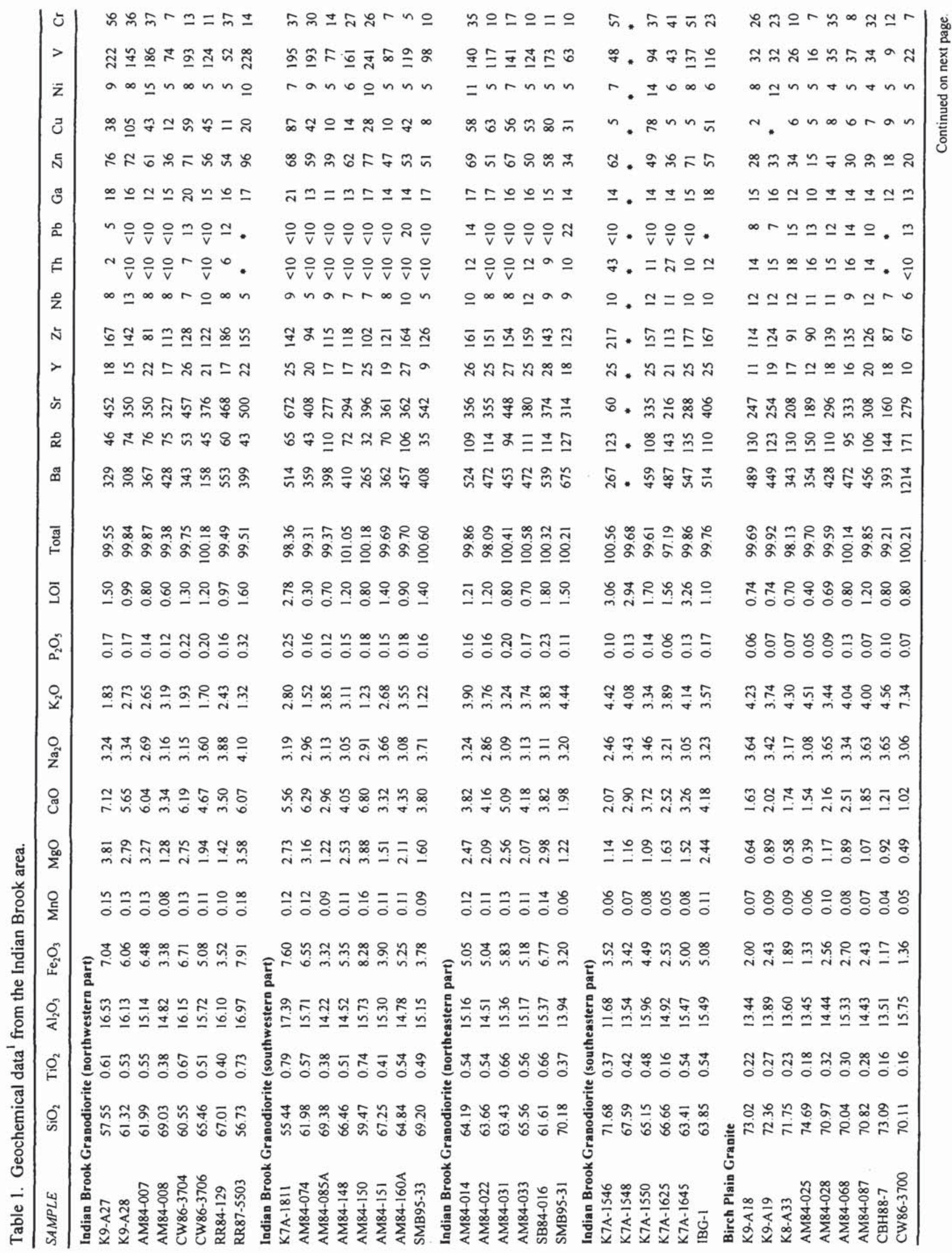




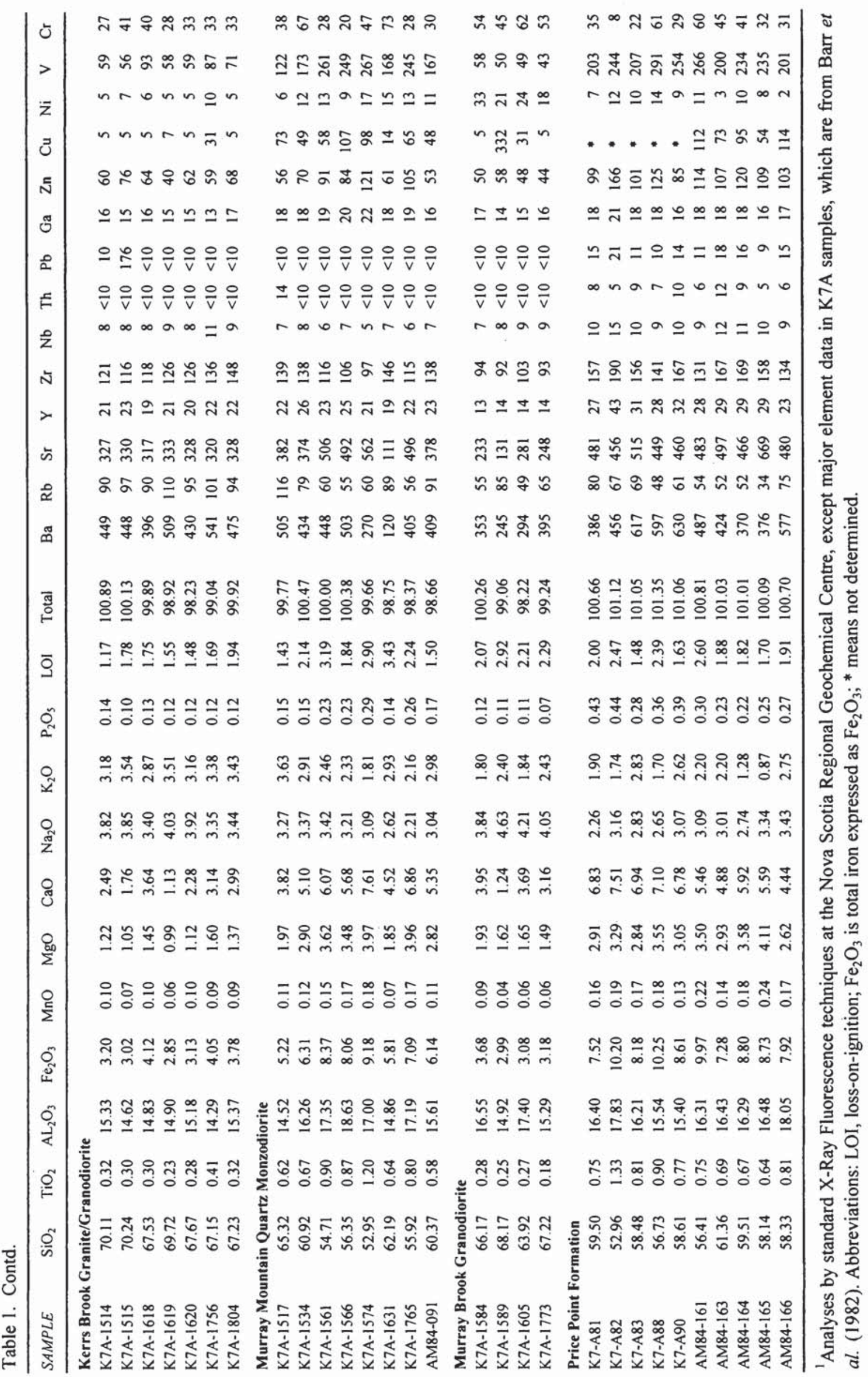




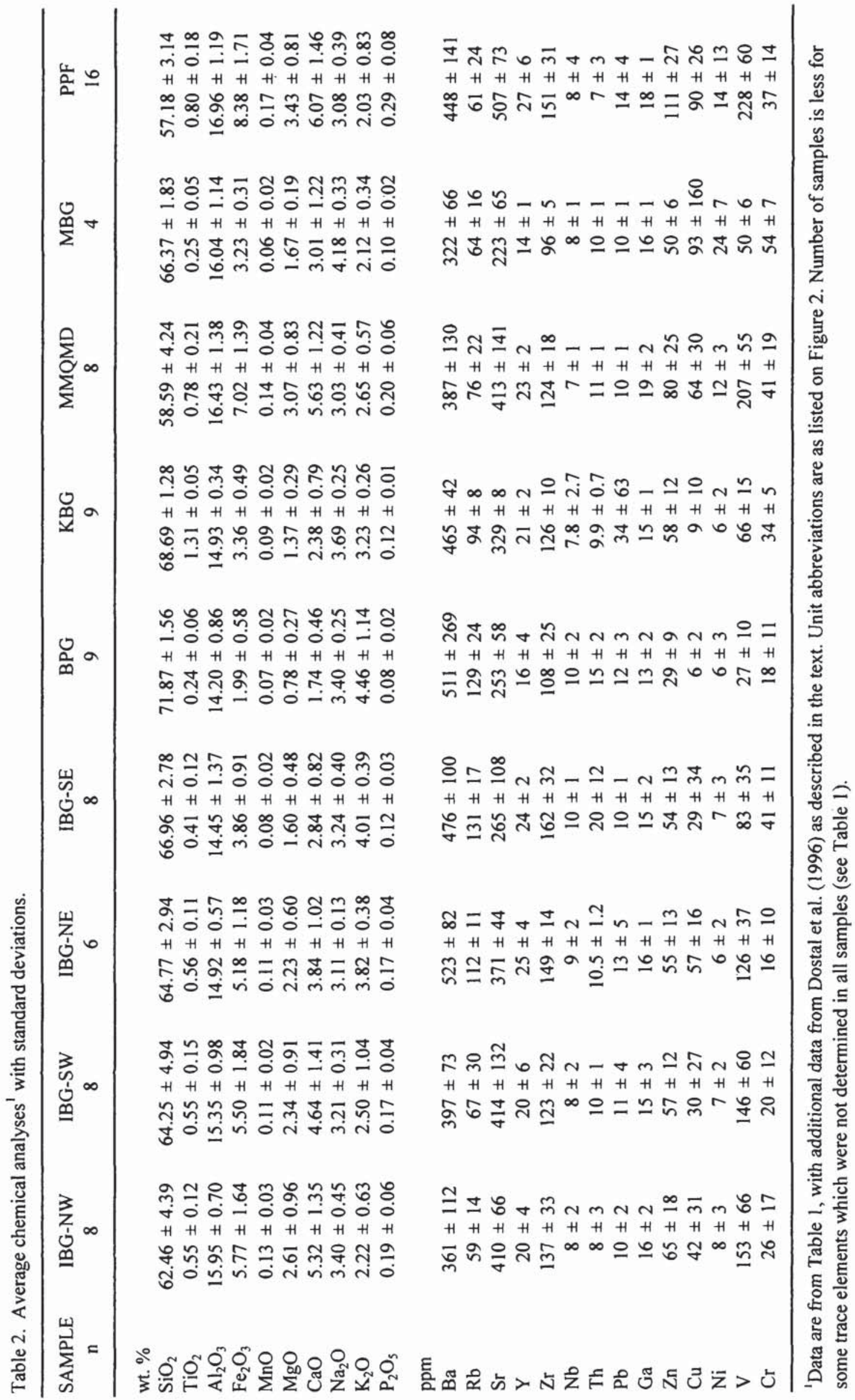



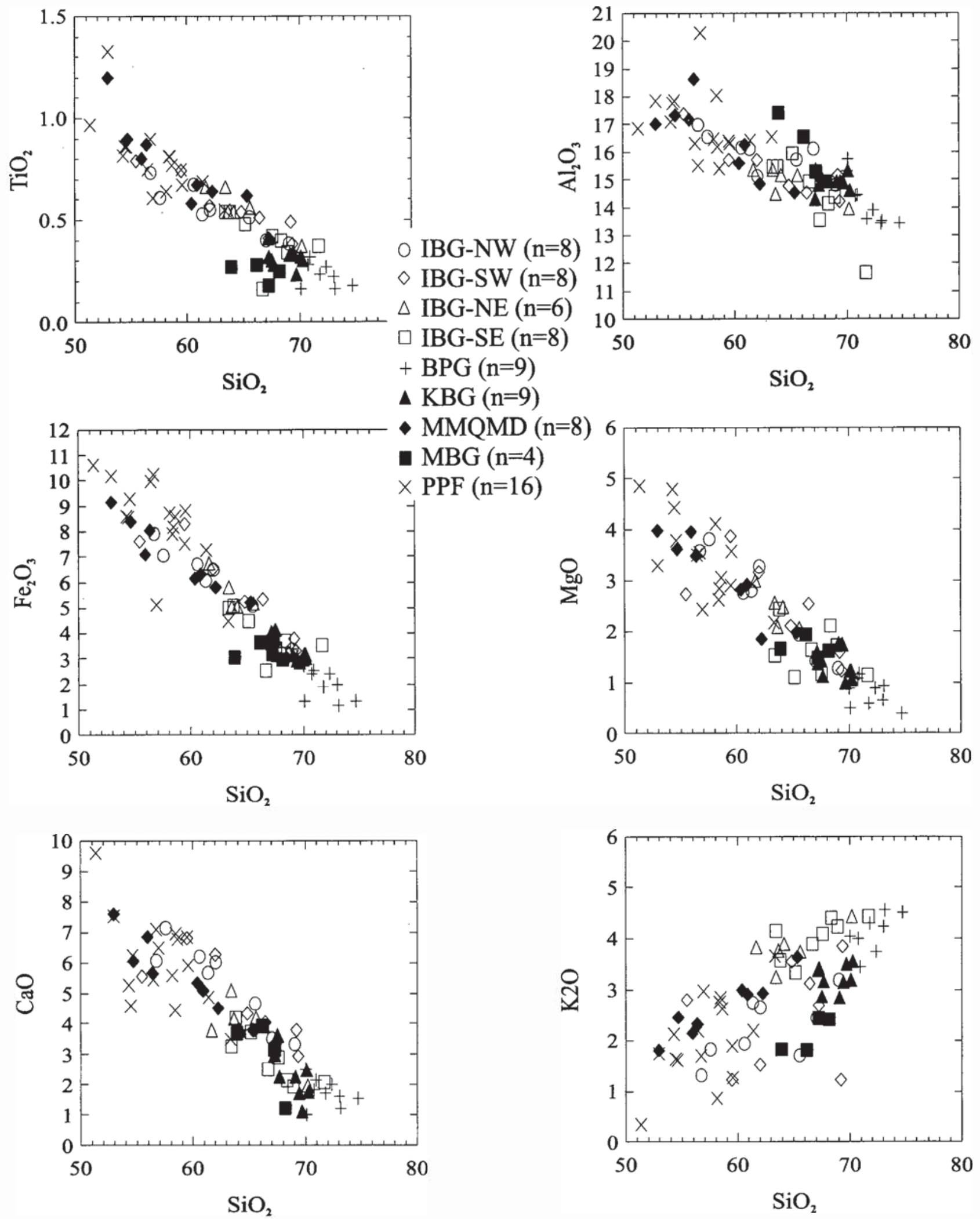

Fig. 2. Selected silica variation diagrams for analysed samples from the Indian Brook area. Abbreviations: IBG-NW, northwestern part of the Indian Brook Granodiorite; IBG-SW, southwestern part of the Indian Brook Granodiorite; IBG-NE, northeastern part of the Indian Brook Granodiorite; IBG-SE, southeastern part of the Indian Brook Granodiorite; KBG, Kerrs Brook Granite; PBG, Birch Plain Granite; MBG, Murray Brook Granodiorite; MMQMD, Murray Mountain Quartz Monzodiorite; PPF, Price Point Formation. 


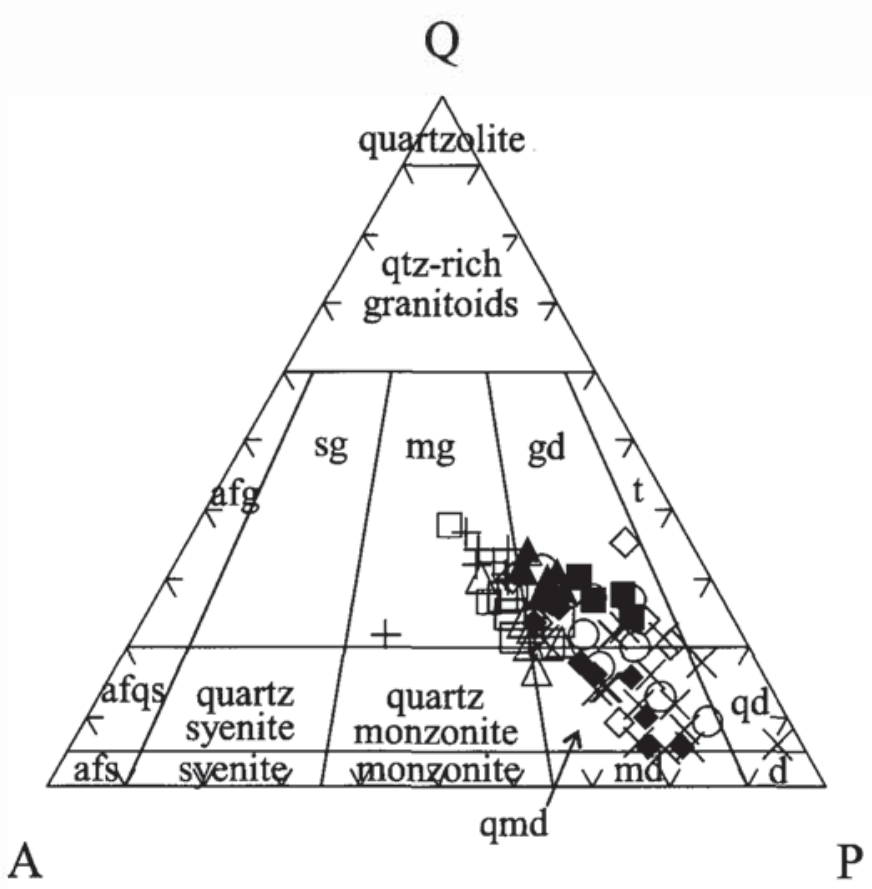

Fig. 3. Ternary plot of CIPW normative quartz (Q), orthoclase (A), and albite + anorthite (P), with fields from Streckeisen (1976). CIPW normative mineralogy was calculated assuming an $\mathrm{Fe}_{2} \mathrm{O}_{3} / \mathrm{FeO}$ ratio of 0.15 . Symbols are as in Fig. 2. Abbreviations: afg, alkali feldspar granite; afs, alkali feldspar syenite; afqs, alkali feldspar quartz syenite; d, diorite; gd, granodiorite; md, monzodiorite; mg, monzogranite; qd, quartz diorite; qmd, quartz monzodiorite; sg, syenogranite; $t$, tonalite.

$\mathrm{SiO}_{2}$ content (67.2 to $70.2 \%$ ), and a significantly lower average $\mathrm{SiO}_{2}$ content $(68.7 \%)$ than the Birch Plain Granite (71.9\%). In most chemical features, the Kerrs Brook Granite appears intermediate between the southeastern part of the Indian Brook Granodiorite and the Birch Plain Granite, but shows some distinctive features such as lower $\mathrm{K}_{2} \mathrm{O}$ and higher $\mathrm{Pb}$ (Fig. 2, 4b).

\section{Murray Brook Granodiorite}

Only four samples have been analysed from this small unit, and they have an average $\mathrm{SiO}_{2}$ content of $66.4 \%$, similar to the samples from the southeastern part of the Indian Brook Granodiorite (Table 2; Fig. 2). However, they are lower in Rb, $\mathrm{Ba}, \mathrm{Th}, \mathrm{K}, \mathrm{Nb}, \mathrm{Sr}, \mathrm{P}, \mathrm{Zr}, \mathrm{Ti}, \mathrm{V}$, and $\mathrm{Y}$, and higher in $\mathrm{Al}$. Some of these differences may be related to the pervasive alteration in the Murray Brook Granodiorite.

\section{Murray Mountain Quartz Monzodiorite}

Eight analysed samples from the Murray Mountain Quartz Monzodiorite have generally lower $\mathrm{SiO}_{2}$ contents than the other granitoid units, consistent with the more mafic modal mineralogy and lower quartz and K-feldspar contents. The average value is $58.6 \%$, but the samples show a range from $53 \%$ to $65.3 \%$. They overlap in $\mathrm{SiO}_{2}$ content with samples from the northwestern, southwestern, and northeastern parts of
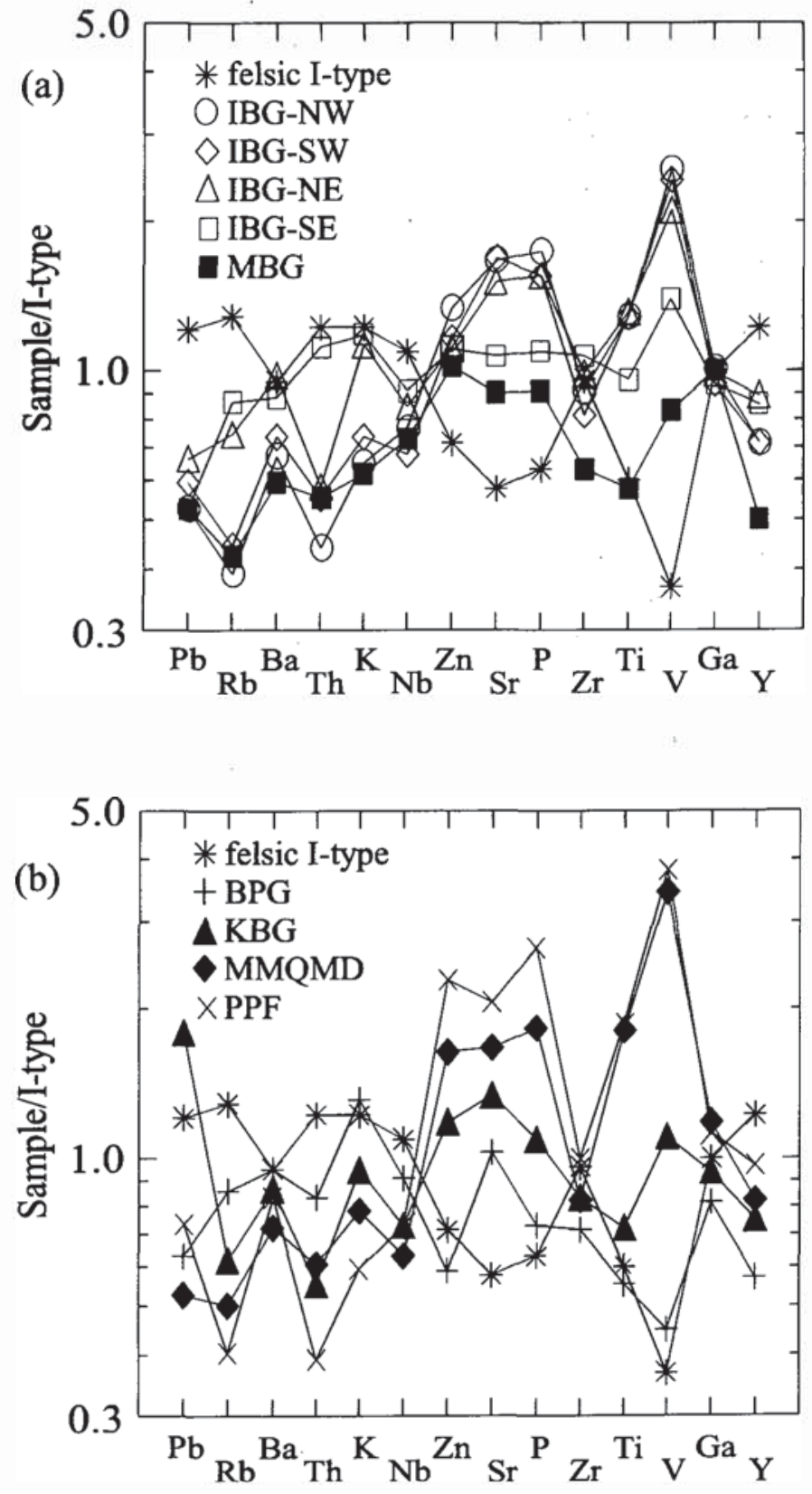

Fig. 4. Multi-element variation diagrams for average analyses of Table 2, normalized against the average I-type granite of Whalen et al. (1987). Average felsic I-type of Whalen et al. (1987) is shown for comparison. Abbreviations are as in Fig. 2.

the Indian Brook Granodiorite, to which they are chemically similar (Fig. 2, 3, 4). However, they show the most striking chemical similarity to the Price Point Formation, as described below.

\section{Price Point Formation}

The chemical data base for the Price Point Formation includes ten samples from the present study, combined with 6 analyses from Dostal et al. (1996). Locations and petrography of the latter samples are unknown. Three dyke samples from Dostal et al. (1996) are excluded because of the possibility 
(noted above) that such dykes are unrelated to the formation. The samples show a range in $\mathrm{SiO}_{2}$ contents similar to that in the spatially associated Murray Mountain Quartz Monzodiorite, and the average value is only $1 \%$ lower at $57.18 \%$. The volcanic samples show more chemical variation, particularly in the more mobile elements such as $\mathrm{Ca}$ and $\mathrm{K}$, but display the same trends as the plutonic samples (Fig. 2, 3). The multi-element variation diagram shows the similarity between the Price Point Formation and the Murray Mountain Quartz Monzodiorite, notably in $\mathrm{Nb}, \mathrm{Ti}, \mathrm{V}, \mathrm{Ga}$, and Y (Fig. 4b).

\section{Discussion}

The ranges in chemical composition correspond well with variations in the proportions of feldspars and mafic minerals in the units, and these variations seem to be gradational. The data are consistent with the interpretation that the samples represent a comagmatic suite. Taken as a group, the samples range more or less continuously from mafic to felsic, but most are intermediate ( 52 to $66 \% \mathrm{SiO}_{2}$ ). Most major element oxides display linear trends on silica variation diagrams (Fig. 2); $\mathrm{TiO}_{2}, \mathrm{Al}_{2} \mathrm{O}_{3}, \mathrm{Fe}_{2} \mathrm{O}_{3}$ t, $\mathrm{MnO}$ (not shown), $\mathrm{MgO}, \mathrm{CaO}$ and $\mathrm{P}_{2} \mathrm{O}_{5}$ display good negative correlations with silica, whereas $\mathrm{K}_{2} \mathrm{O}$ displays positive correlation with $\mathrm{SiO}_{2}$. The $\mathrm{Na}_{2} \mathrm{O}$ contents are approximately constant at ca. $3 \%$ (Table 2). Overall, the chemical variations within each pluton and among the plutons as a group suggest a major role for crystal fractionation in magma evolution. Plots of $\mathrm{Rb}$ versus $\mathrm{Sr}$ and $\mathrm{Ba}$ versus $\mathrm{Sr}$ (Fig. $5 \mathrm{a}, \mathrm{b})$ show patterns qualitatively consistent with fractionation dominated by plagioclase and hornblende, with evidence for $\mathrm{K}$-feldspar and biotite removal in the granitic samples. However, the presence of distinct mappable units, each with internal variations and compositional overlaps with other units, suggests that each unit may represent an individual magma, generated from the same or similar source rocks by different amounts partial melting and then subject to fractional crystallization. In this sense, the separate plutonic and volcanic units may be considered cogenetic but not directly comagmatic. The probable exception to this interpretation may be the Price Point volcanic rocks and the spatially associated Murray Mountain Quartz Monzodiorite.

A variety of chemical parameters, as well as the petrographic characteristics of the rocks, indicate that they are calc-alkalic, such as trends on the AFM diagram (Fig. 6), on which the more evolved composition of the Birch Plain Granite compared to the other units is very clear. The tectonic setting is clearly a volcanic arc (Fig. 7), and overall, the compositions are typical of compositionally expanded calcalkaline I-type suites formed in association with continentalmargin subduction zones (e.g., Pitcher 1982, Brown et al. 1984), as also concluded by Dostal et al. (1996).

\section{RARE-EARTH ELEMENT DATA}

Dostal et al. (1996) published REE data for six volcanic samples from the Price Point Formation, two samples from the Indian Brook Granodiorite, and two samples from the Kerrs Brook Granite. We contribute previously unpublished analyses
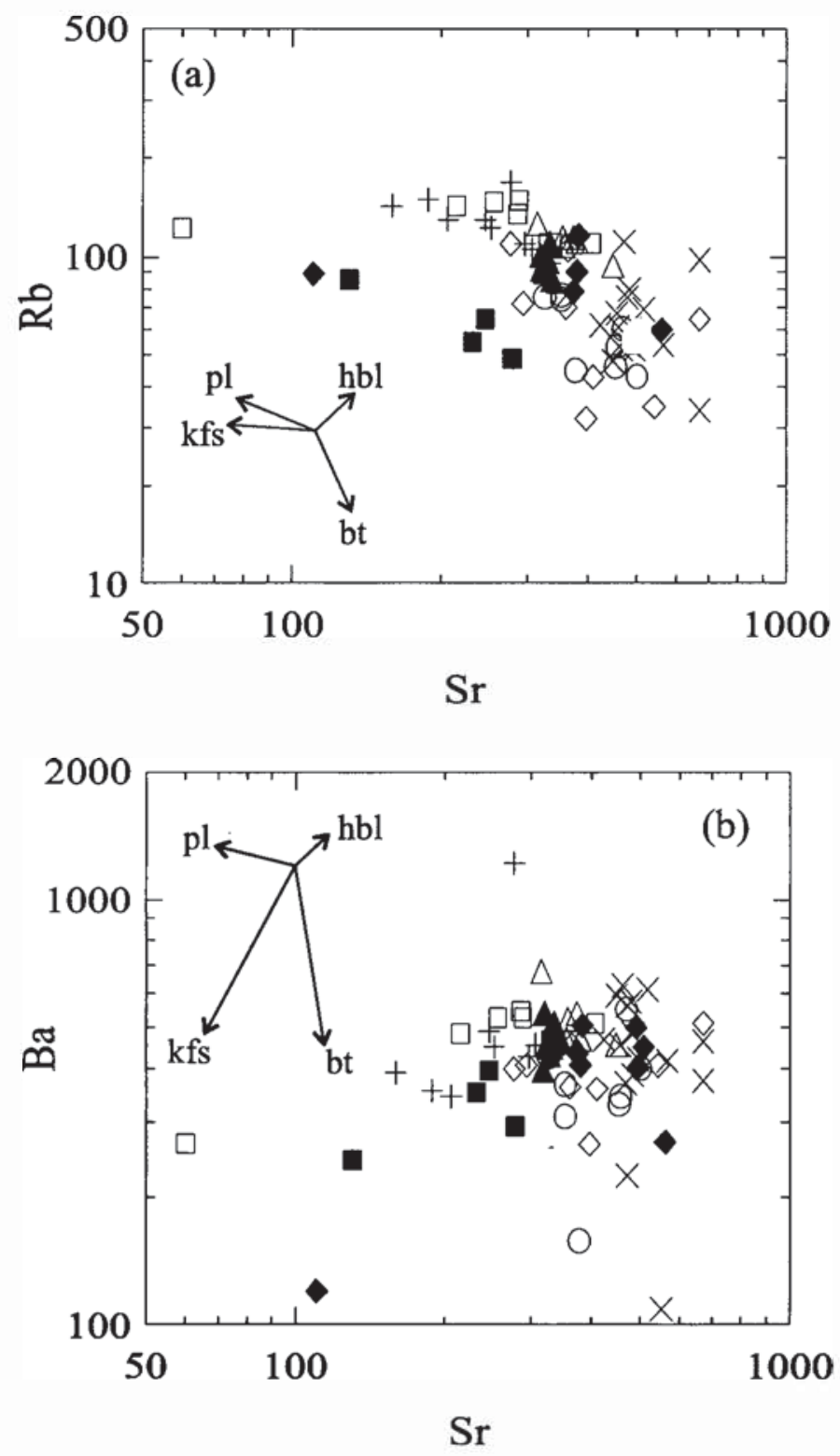

Fig. 5. Plots of (a) $\mathrm{Rb}$ against $\mathrm{Sr}$ and (b) $\mathrm{Ba}$ against $\mathrm{Sr}$. Approximate mineral fractionation vectors for plagioclase (pl), homblende ( $\mathrm{hbl})$, biotite $(\mathrm{bt})$, and potassium feldspar ( $\mathrm{kfs})$ are shown, after Farrow and Barr (1992), as a qualitative indication of the effects of removal of these minerals on magma evolution. Symbols are as in Fig. 2.

for two additional samples from the Indian Brook Granodiorite (one each from the southeastern and northwestern areas) and two samples from the Birch Plain Granite (Table 3). The chondrite-normalized patterns for all samples are similar in shape, showing light REE enrichment, a slight negative Eu anomaly, and gently downward-sloping heavy REE (Fig. 8a, $b$, c). The lower REE contents, especially light REE, in more felsic samples may be due to their lower content of REEbearing accessory phases such as titanite, which may have been removed by crystal fractionation.

Based on their samples, Dostal et al. (1996) suggested that the volcanic rocks of the Price Point Formation may have had a different source than the plutonic rocks because of the 


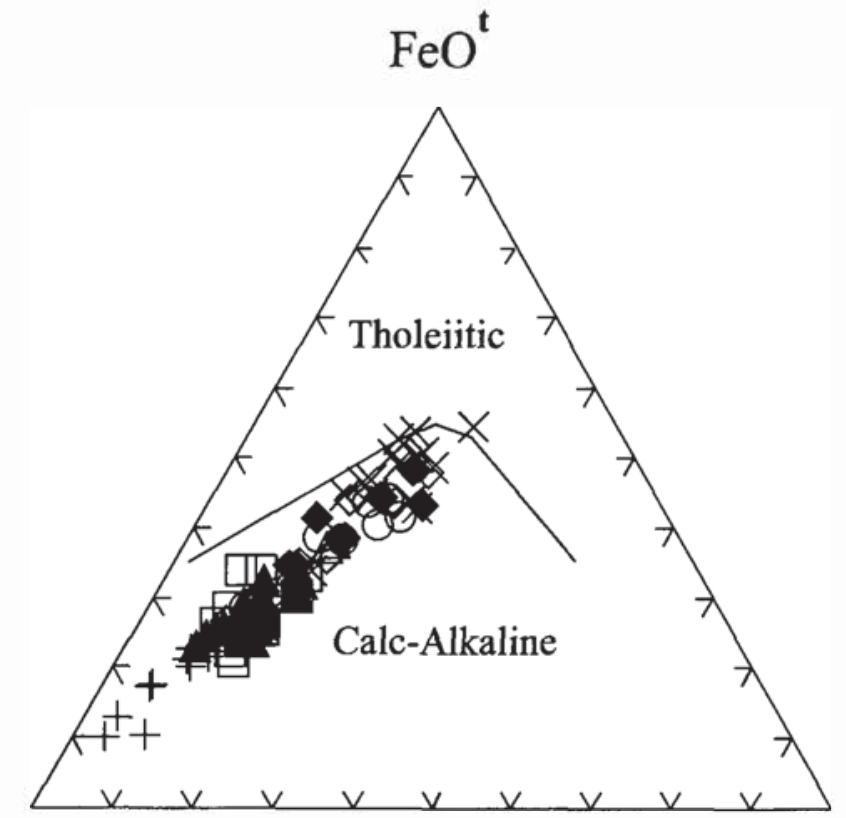

$\mathrm{Na}_{2} \mathrm{O}+\mathrm{K}_{2} \mathrm{O}$

$\mathrm{MgO}$

Fig. 6. Temary AFM diagram, with tholeiitic/calc-alkaline dividing line from Irvine and Baragar (1971). Symbols are as in Fig. 2.

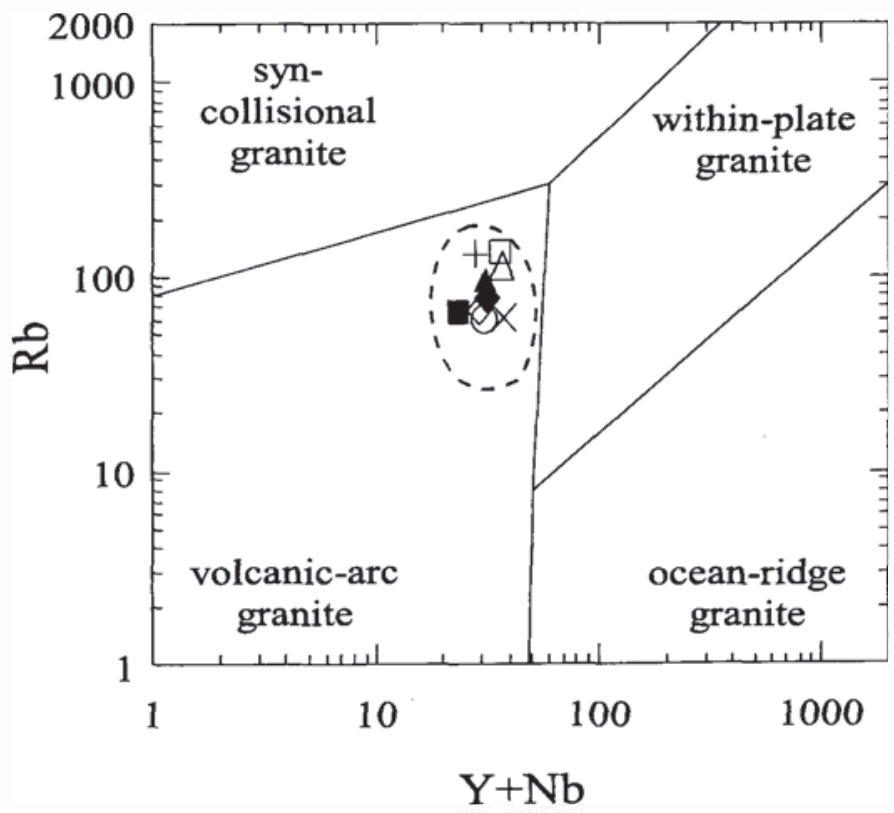

Fig. 7. Rb against $\mathrm{Y}+\mathrm{Nb}$, with fields from Pearce et al. (1984). Average analyses of units (with symbols as in Fig. 4) are shown; the dashed field encloses most of the samples.

differences, for example, in heavy REE patterns. However, most of the samples analyzed by Dostal et al. (1996) are basaltic. The REE pattern for their most felsic sample (P-17; $63.33 \% \mathrm{SiO}_{2}$ ) has a REE pattern very similar to that of the Indian Brook Granodiorite (Fig. 8b). The data, although admittedly limited, support the overall chemical similarity among volcanic and plutonic units in the area.
Table 3. Rare-earth element data (in ppm) from the Indian Brook Granodiorite (IBG) and Birch Plain Granite (BPG).

\begin{tabular}{|c|c|c|c|c|}
\hline SAMPLE & $\begin{array}{l}\text { IBG-NW } \\
\text { K9-A28 }\end{array}$ & $\begin{array}{l}\text { IBG-SE } \\
\text { IBG-1 }\end{array}$ & $\begin{array}{c}\text { BPG } \\
\text { K9-A18 }\end{array}$ & $\begin{array}{c}\text { BPG } \\
\text { AM84-028 }\end{array}$ \\
\hline $\mathrm{La}$ & 27.57 & 31.26 & 16.31 & 27.52 \\
\hline $\mathrm{Ce}$ & 62.54 & 69.18 & 36.18 & 58.66 \\
\hline $\mathrm{Nd}$ & 24.85 & 30.87 & 11.94 & 22.00 \\
\hline $\mathrm{Sm}$ & 4.13 & 6.15 & 2.15 & 4.21 \\
\hline $\mathrm{Eu}$ & 1.54 & 1.44 & 0.65 & 0.99 \\
\hline $\mathrm{Tb}$ & 0.47 & 0.71 & 0.33 & 0.50 \\
\hline $\mathrm{Yb}$ & 1.74 & 2.49 & 1.20 & 1.85 \\
\hline $\mathrm{Lu}$ & 0.28 & 0.36 & 0.19 & 0.28 \\
\hline
\end{tabular}

'Analyes by Instrumental Neutron Activation at St. Mary's University, Halifax, NS. Whole-rock analyses for samples are in Table 1. Unit abbreviations as in Figure 2.

\section{AMPHIBOLE COMPOSITIONS IN THE INDIAN BROOK GRANODIORITE}

Farrow and Barr (1992) reported that amphibole in samples from the western part of the Indian Brook Granodiorite contains higher $\mathrm{Al}_{2} \mathrm{O}_{3}$ than amphibole in samples from the eastern part. They interpreted this difference to indicate that the western part represents deeper levels of crystallization, based on the hornblende geobarometer (Hammarstrom and Zen 1986; Hollister et al. 1987; Johnson and Rutherford 1989; Schmidt 1992). To further investigate this difference, additional analyses were done on amphibole in some of the samples studied by Farrow and Barr (1992), and analyses were also obtained of amphibole from two additional samples. Representative analyses from the 11 samples are presented in Table 4.

Most of the amphiboles are classified as magnesiohornblende (Fig. 9). Although compositions vary within each sample, hornblende in samples from both the northwestern and southwestern parts of the pluton tends to have lower $\mathrm{Mg} / \mathrm{Mg}+\mathrm{Fe}$ ratio and tetrahedral $\mathrm{Si}$ content compared to hornblende in samples from the northeastern and southeastern parts (Fig. 9), as well as higher Al content (Table 4). The differences in hornblende composition are reflected in colour differences in thin section. Hornblende in samples from the western part of the pluton is blue-green to pale yellow whereas in samples from the eastern part, the hornblende lacks blue-green colour and is pleochroic from green to yellowgreen.

The Indian Brook Granodiorite contains the appropriate mineral assemblage (quartz + plagioclase + K-feldspar + hornblende + biotite + titanite + an oxide phase) for use of the Al-in-hornblende geobarometer. Although the use of this geobarometer has been controversial (e.g., Anderson 1997), the rationale for its use has also been well documented (e.g., Leake and Said 1994; Ague and Brandon 1997). The higher Al contents in hornblende in samples from the northwestern and 

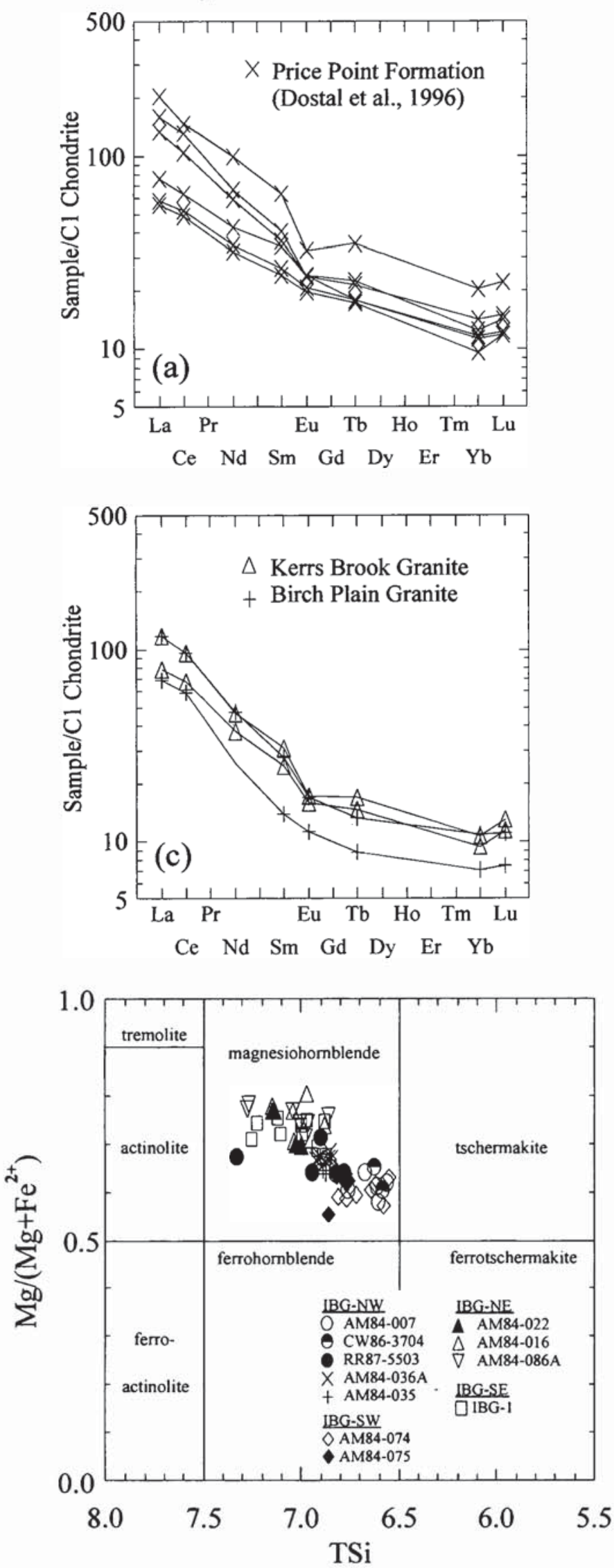

Fig. 9. Classification of calcic amphiboles with $\mathrm{Na}+\mathrm{K}<0.5$ and $\mathrm{Ti}$ $<0.5$, criteria which apply to most of the analyzed amphiboles in the Indian Brook Granodiorite. Classification diagram is after Leake et al. (1997).

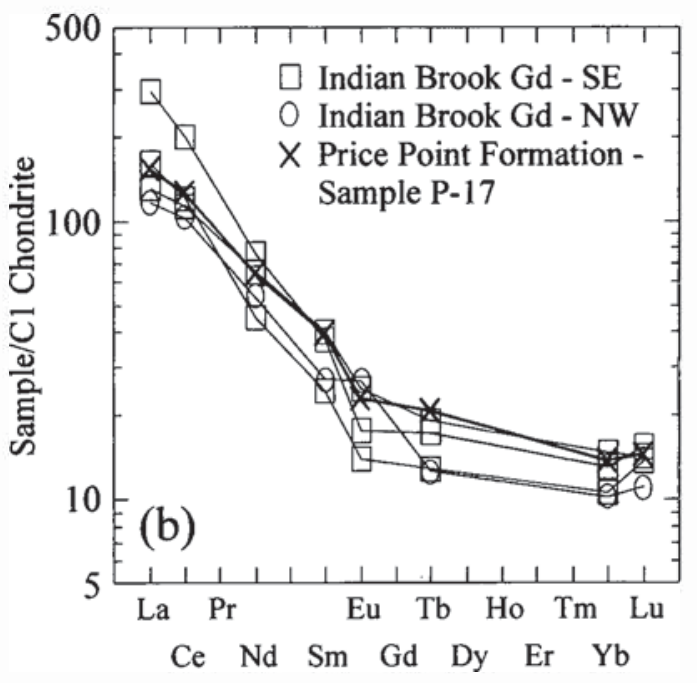

Fig. 8. Chondrite-normalized REE diagrams for (a) volcanic rocks of the Price Point Formation (data from Dostal et al. 1996), (b) samples from the Indian Brook Granodiorite, with sample P-17 $\left(66.33 \% \mathrm{SiO}_{2}\right)$ from the Price Point Formation shown for comparison (data from Dostal et al. 1996, and Table 3), and (c) samples from the Kerrs Brook Granite (data from Dostal et al. 1996) and Birch Plain Granite (data from Table 3). Chondrite-normalizing values are from Sun and McDonough (1989).

southwestern areas suggest higher pressures of crystallization (Table 5). The calculated pressures are consistent with crystallization of the western part of the Indian Brook Granodiorite at mesozonal to catazonal depths, whereas the eastern part crystallized at epizonal depths. This variation in the level of emplacement is compatible with the variation in the metamorphic grade in the area, because the western margin of the Indian Brook Granodiorite contains abundant gneissic xenoliths from the Barachois River Metamorphic Suite, whereas the southeastern part is associated with lowgrade metavolcanic rocks of Price Point Formation (Raeside and Barr 1990). The data are also consistent with compositional variations in the Indian Brook Granodiorite, which becomes more felsic toward the southeast.

\section{Conclusions}

The continental margin-volcanic arc setting for magmatism in the Indian Brook area is consistent with the abundance of Late Neoproterozoic arc-related plutons elsewhere in the Bras d'Or terrane (Raeside and Barr 1990; Farrow and Barr 1992; Justino and Barr 1994; Keppie et al. 1998). Units of similar age also occur in the Coastal belt of the Mira terrane (Barr et al. 1996), and Dostal et al. (1996) linked 


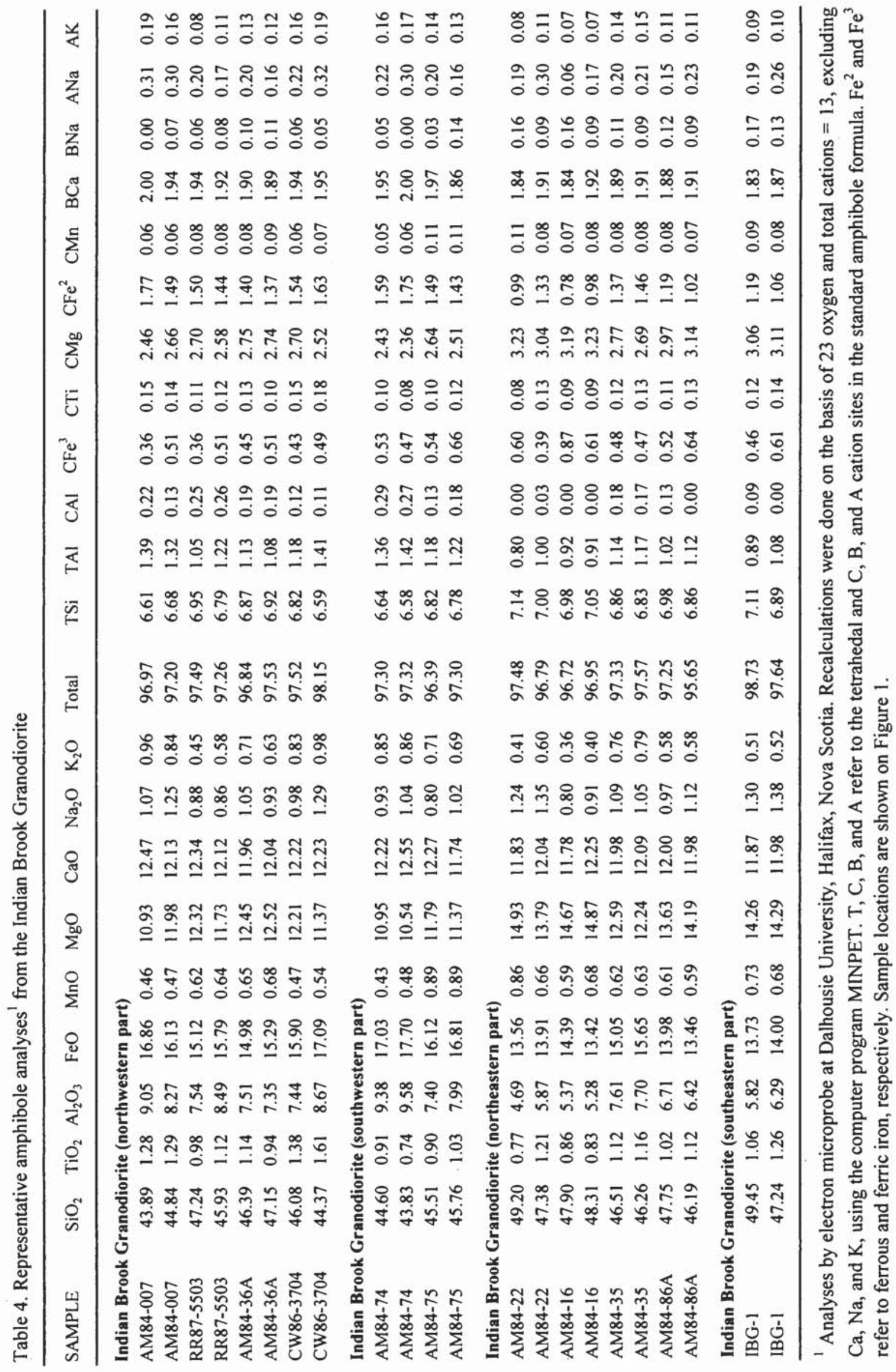


Table 5. Average amphibole data in samples from the Indian Brook Granodiorite*.

\begin{tabular}{lcccc}
\hline & $\mathrm{n}^{1}$ & Alt $^{2}$ & $\mathrm{TSi}^{3}$ & $\begin{array}{c}\mathrm{P}^{4} \\
(\mathrm{kbar})\end{array}$ \\
\hline Northwest & & & & \\
AM-84-7 & 5 & 1.52 & 6.57 & 4.22 \\
CW-3704 & 3 & 1.43 & 6.68 & 3.80 \\
RR-5503 & 4 & 1.24 & 6.99 & 2.89 \\
AM-84-36A & 7 & 1.29 & 6.88 & 3.13 \\
AM-84-35 & 7 & 1.30 & 6.88 & 3.18 \\
Southwest & & & & \\
AM-84-74 & 7 & 1.60 & 6.67 & 4.61 \\
AM-84-75 & 4 & 1.39 & 6.81 & 3.61 \\
Northeast & & & & \\
AM-84-22 & 4 & 1.17 & 6.92 & 2.56 \\
AM-84-16 & 6 & 0.96 & 7.04 & 1.56 \\
AM-84-86A & 7 & 1.01 & 7.06 & 1.80 \\
Southeast & & & & \\
IBG-1 & 11 & 1.05 & 6.98 & 1.99 \\
\hline
\end{tabular}

\footnotetext{
- grouped by area as described in the text.

${ }^{1}$ number of analyses used in the calculation.

${ }^{2}$ average total aluminum content

${ }^{3}$ average total silicon content

${ }^{4}$ pressure calculated using formula of Schmidt (1992)
}

these rocks in the same subduction zone. One problem with this interpretation is that the Coastal belt is separated from the Bras d'Or terrane by older belts of volcanic and plutonic rocks (Stirling, East Bay Hills, and Coxheath Hills belts), which do not show evidence for thermal or tectonic overprinting by ca. 575 - 555 Ma subduction (Barr et al. 1990). Furthermore, isotopic data suggest that the Mira terrane does not have the same type of crust as that under the Bras d'Or terrane (Ayuso et al. 1997; Barr et al. 1998). Hence, we suggest that linking the volcanic and plutonic rocks of the Indian Brook area (and other parts of the Bras d'Or terrane) with compositionally different volcanic and plutonic rocks of the Coastal belt in the Mira terrane on the basis of similar age is not a viable model.

No evidence has been documented to separate the units of this study from those to the northwest by a major structural break, as proposed by Lynch and Lafrance (1996) and Lynch (1996). The previous interpretation (Farrow and Barr 1992) that progressively higher crustal levels are exposed from northwest to southeast across the southeastern Cape Breton Highlands is supported by the present study but the change appears gradual across the Indian Brook Granodiorite, and does not take place at an inferred major thrust along its western margin. The presence of xenoliths of diorite, tonalite, and gneiss in the western part of the Indian Brook Granodiorite further suggests that the contacts with adjacent units to the northwest are intrusive. However, the western margin of the Indian Brook Granodiorite is difficult to access and not yet well mapped, and the nature of the Barachois
River Metamorphic Suite is not yet known. This area should clearly be the target of future study.

\section{ACKNOWLEDGEMENTS}

This project was undertaken while the senior author was a visiting scientist at Acadia University (1995-96). She acknowledges the support of the National Research Council of Argentina (CONICET) and the Universidad Nacional del Sur that enabled her to work at Acadia University. The field work and sample collection on which the present study is based were done mainly during regional mapping of the southeastern Cape Breton Highlands by S.M. Barr, A.S. Macdonald, and R.P. Raeside. The substantial contributions of the latter two colleagues are gratefully acknowledged. Analytical work was funded by NSERC research grants to S.M. Barr. We are grateful to Joanne Price for drafting the diagrams. Helpful comments from journal reviewers Linda Ham and Jarda Dostal resulted in significant improvements in the manuscript.

Ague, J.J. and Brandon, M.T. 1997. Regional tilt of the Mount Stuart batholith, Washington, determined using aluminum-inhomblende barometry: Implications for northward translation of Baja British Columbia: Reply. Geological Society of America Bulletin, 109, pp. 1225-1227.

ANDERSON, J.L. 1997. Regional tilt of the Mount Stuart batholith, Washington, determined using aluminum-in-homblende barometry: Implications for northward translation of Baja British Columbia: Discussion. Geological Society of America Bulletin, 109, pp. 1223-1225.

AYUSO, R.A., BARR, S.M., and LONGSTAFFE, F.J. 1996. Pb and O isotopic constraints on the source of granitic rocks from Cape Breton Island, Nova Scotia. American Journal of Science, 296, pp. 789-817.

BARR, S.M. and RAESIDE, R.P. 1989. Tectono-stratigraphic terranes in Cape Breton Island, Nova Scotia: Implications for the configuration of terranes in the northern Appalachian Orogen; Geology, 17, pp. 822-825.

BARR, S.M. and WHITE, C.E. 1996. Contrasts in late Precambrianearly Paleozoic tectonothermal history between Avalon composite terrane sensu stricto and the other possible periGondwanan terranes in southern New Brunswick and Cape Breton Island, Canada In Avalonian and Related PeriGondwanan Terranes of the Circum-North Atlantic. Edited by R.D. Nance and M.D. Thompson. Geological Society of America Special Paper 304, pp. 95-108.

BarR, S.M., O'Reilly, G.A., and O'BeIRNE, A.M. 1982. Geology and geochemistry of selected granitoid plutons of Cape Breton Island. Nova Scotia Department of Mines and Energy Paper 82-1, 177p.

BARR, S.M., RAESDE, R.P., and MACDONALD, A.S. 1985. Geological mapping of the southeastern Cape Breton Highlands, Nova Scotia In Current Research, Part B, Geological Survey of Canada Paper 85-1B, pp. 103-109.

BARR, S.M., RAESIDE, R.P., MILlER, B.V., and WhITE, C.E. 1995. Terrane evolution and accretion in Cape Breton Island, Nova Scotia In Current Perspectives in the Appalachian-Caledonian Orogen. Edited by J.P. Hibbard, C.R. van Staal, and P.A. Cawood. Geological Association of Canada, Special Paper 41, pp. 391-407.

BARR, S.M., WhITE, C.E., and MACDONALD, A.S. 1996. Stratigraphy, tectonic setting, and geological history of Late Precambrian volcanic-sedimentary-plutonic belts in southeastern Cape Breton Island, Nova Scotia. Geological Survey of Canada, Bulletin 468 
(accompanied by a 1:100,000 scale geological map).

BARR, S.M., DUNNING, G.R., RAESIDE, R.P., and JAMIESON, R.A. 1990. Contrasting U-Pb ages from plutons in the Bras d'Or and Mira terranes of Cape Breton Island, Nova Scotia. Canadian Journal of Earth Sciences, 27, pp. 1200-1208.

BARR, S.M., RAESIDE, R.P., and JAMIESON, R.A. 1992. Geology of northern Cape Breton Island, Nova Scotia. Geological Survey of Canada Coloured Map 1752A, scale 1:100,000.

BARR, S.M., RAESIDE, R.P., and WhITE, C.E. 1998. Geological correlations between Cape Breton Island and Newfoundland. Canadian Journal of Earth Sciences, 35, pp. 1252-1270.

BROWN, G.C., ThORPE, R.S., and WeBB, P.C. 1984. The geochemical characteristics of granitoids in contrasting arcs and comments on magma sources. Journal of the Geological Society of London, 141, pp. 413-426.

Dostal, J., KePPIE, J.D., Cousens, B.L., and MurPhy, J.B. 1996. 550-580 Ma magmatism in Cape Breton Island Nova Scotia, Canada): the product of NW-dipping subduction during the final stage of amalgamation of Gondwana. Precambrian Research, 76, pp. 93-113.

DUNNING, G.R., BARR, S.M., RAESIDE, R.P., and JAMIESON, R.A. 1990. U-Pb zircon, titanite and monazite ages in the Bras d'Or and Aspy terranes of Cape Breton Island, Nova Scotia: implications for igneous and metamorphic history. Geological Society of America Bulletin, 102, pp. 322-330.

FARROW, C.E.G. 1989. Petrography, Mineral Chemistry and Geochemistry of Dioritic and Tonalitic Plutons of the Southeastern Cape Breton Highlands, Nova Scotia. Unpublished M.Sc. thesis, Acadia University, Wolfville, Nova Scotia.

FARROW, C.E.G. and BARR, S.M. 1992. Petrology of high-Alhomblende and magmatic epidote bearing plutons in the southeastern Cape Breton Highlands, Nova Scotia. Canadian Mineralogist, 30, pp. 377-392.

HAMMARSTROM, J.M. and ZEN, E-An 1986. Aluminum in hornblende: an empirical igneous geobarometer. American Mineralogist, 71, pp. 1297-1313.

HANSON, G.N. 1980. Rare earth elements in petrogenetic studies of igneous systems. Annual Reviews of Earth and Planetary Sciences, 8, pp. 371-406.

Hollister, L.S., Grissom, G.C., Peters, E.K., Stowell, H.H., and SISSON, V.B. 1987. Confirmation of the empirical correlation of $\mathrm{Al}$ in homblende with pressure of solidification of calc-alkaline plutons. American Mineralogist, 72, pp. 231-239.

IRVINE, T.N. and BARAGAR, W.R.A. 1971. A guide to the chemical classification of the common volcanic rocks. Canadian Journal of Earth Sciences, 8, pp. 523-548.

JOHNSON, M.C. and RUTHERFORD, M.J. 1989. Experimental calibration of the aluminum-in-homblende geobarometer with application to Long Valley caldera (California) volcanic rocks. Geology 17, pp. 837-841.

JUSTINO, M. and BARR, S.M. 1994. Petrology, petrogenesis, and tectonic setting of plutonic rocks in the North Mountain area, west-central Cape Breton Island, Nova Scotia. Atlantic Geology, 30, pp. 47-64.

KePPIE, J.D., DAVIS, D.W., and KROGH, T.E. 1998. U-Pb geochronological constraints on Precambrian stratified units in the Avalon Composite Terrane of Nova Scotia, Canada: tectonic implications. Canadian Journal of Earth Sciences, 35, pp. 222 236.
KePPIE, J.D., DallmeYer, R.D., and MURPhy, J.B. 1990. Tectonic implications of ${ }^{40} \mathrm{Ar} /{ }^{39} \mathrm{Ar}$ homblende ages from late ProterozoicCambrian plutons in the Avalon Composite Terrane, Nova Scotia, Canada. Geological Society of America Bulletin, 120, pp. 516-528.

LEAKE, B.E. and 21 others. 1997. Nomenclature of amphiboles: report of the Subcommittee on Amphiboles of the International Mineralogical Association, Commission on New Minerals and Mineral Names. Canadian Mineralogist, 35, pp. 219-246.

LEAKE, B.E. and AHMED SAID, Y. 1994. Hornblende barometry of the Galway batholith, Ireland: an empirical test. Mineralogy and Petrology, 51, pp. 243-250.

LYNCH, G. 1996. Tectonic burial, thrust emplacement, and extensional exhumation of the Cabot nappe in the Appalachian hinterland of Cape Breton Island, Canada. Tectonics, 15, pp. 94105.

LynCH, G. and LaFrance, B. 1996. Bedrock geology, St. Anns $(11 \mathrm{~K} / 07)$. Geological Survey of Canada, Open File 3059, Scale $1: 50,000$.

MACDONALD, A.S. and BARR, S.M. 1985. Geology and age of polymetallic mineral occurrences in volcanic and granitoid rocks, St. Ann's area, Cape Breton Island, Nova Scotia. In Current Research, Part B, Geological Survey of Canada, Paper 85-1B, pp. 117-124.

PEARCE, J.A., Harris, N.B.W., and Tindle, A.G. 1984. Trace element discrimination diagrams for the tectonic interpretation of granitic rocks. Journal of Petrology, 25, pp. 956-983.

PITCHER, W.S. 1982. Granite type and tectonic environment. In Mountain Building Processes. Edited by K.J. Hsu. Academic Press, New York, pp. 19-40.

RAESIDE, R.P. and BARR, S.M. 1990. Geology and tectonic development of the Bras d'Or suspect terrane, Cape Breton Island, Nova Scotia. Canadian Journal of Earth Sciences, 27, pp. 1371-1381.

RAESIDE, R.P. and BARR, S.M. 1992. Geology of the northern and eastern Cape Breton Highlands, Nova Scotia. Geological Survey of Canada. Paper 89-14.

ScHMIDT, M.W. 1992. Amphibole composition in tonalite as a function of pressure: an experimental calibration of the Al-inhornblende barometer. Contributions to Mineralogy and Petrology, 110, pp. 304-310.

STRECKEISEN, A. 1976. To each plutonic rock its proper name. Earth Science Reviews, 12, pp. 1-33.

SuN, S.S. and MCDONOUGH, W.F. 1989. Chemical and isotopic systematics of oceanic basalts: implications for mantle composition and processes. In Magmatism in the ocean basins. Geological Society of London, Special Publication, 42, pp. 313345.

WHITE, C.E. and BARR, S.M. 1996. Geology of the Brookville terrane, southern New Brunswick, Canada. In Avalonian and related peri-Gondwanan terranes of the Circum-North Atlantic. Edited by R.D. Nance and M.D. Thompson. Geological Society of America, Special Paper 304, pp. 133-148.

Whalen, J.B., CurRIE, K.L., and Chappell, B.W. 1987. A-type granites: geochemical characteristics, discrimination, and petrogenesis. Contributions to Mineralogy and Petrology, 95, pp. 407-419. 